История педагогики и образования [Електронний ресурс] / М. Мазалова. - Режим доступу: http://royallib.com/book/mazalova_marina/istoriya_pedagogiki_i_obrazovaniya.html.

13. Максимюк С. П. Педагогіка: [навчальний посібник] / С. П. Максимюк. - Київ : Кондор, 2005. - 667 с. 14. Мешко О. I. Історія зарубіжної школи і педагогіки / О. І. Мешко, О. І. Янкович, Г. М. Мешко. - Тернопіль : ТДПУ, 1996. - 207 с. 15. Пискунов А. История педагогіки / А. Пискунов. - Москва : ТЦ «Сфера», 1998. - 304 с. 16. Попов В. А. История педагогики и образования / В. А. Попов; под ред. В. А. Сластенина. - Москва : Издательский центр «Академия», 2012. - 208 с. 17. Пряникова В. Г. История образования и педагогической мысли: [учебник-справочник] / В. Г. Пряникова, 3. И. Равкин.- Москва : Новая школа, 1995. - 96 с. 18. Степашко Л. А. Философия и историяобразования / Л. А. Степашко. - Москва : Московский психолого-социальный институт: Флинта, 1999. 272 c. 19. Фіцула М. М. Педагогіка / $\quad$ М. М. Фіцула. - Київ : Академія, 2001. $-527 \mathrm{c}$.

УДК 371.12

Володимир Марків

\title{
ПЕДАГОГІЧНА ДІЯЛЬНІСТЬ НАРОДНИХ ШКІЛ ПІВДЕННО-СХІДНОЇ УКРАЇНИ У ХІХ СТОЛІТТІ (ІСТОРИКО-ПЕДАГОГІЧНИЙ АСПЕКТ)
}

Марків В.М. Педагогічна діяльність народних шкіл Південно-Східної України у XIX столітті (історико-педагогічний аспект).

У статті розглядається питання формування вчительського персоналу в XIX столітті для початкових класів. Історичний контекст становить XVIII - на початку XIX століття, коли відбувається активний процес колонізації Північного Причорномор'я (побудова нові міст Херсона, Миколаєва, Одеси, великої кількості містечок і сіл; розвиток промисловості, торгівлі, суднобудування, сільське господарства; виникнення і функціонування перших осередків освіти - народних шкіл, актуалізація питання щодо їх кадрового складу).

Ключові слова: народні школи, кадровий склад, ланки освіти, осередки освіти, учительські кадри, педагогічні знання, підготовка вчителів, професійний педагог, початкова школа.

Маркив В. Н. Педагогическая деятельность народных школ Юго-Восточной Украины в XIX веке (историко-педагогический аспект).

В статье рассматривается вопрос формирования учительского персонала в XIX веке для начальных классов. Исторический контекст составляет XVIII - нач. XIX века, когда происходит активный процесс колонизации Северного Причерноморья (построение новые городов - Херсона, Николаева, Одессы, большого количества городов и сел, развитие промышленности, торговли, судостроения, сельское хозяйства, возникновение и функционирование первых очагов образования - народных школ, актуализация вопроса их кадрового состава).

Ключевые слова: народные школы, кадровый состав, звенья образования, ячейки образования, учительские кадры, педагогические знания, подготовка учителей, профессиональный педагог, начальная школа.

Markiv V. N. Educational activity of folk schools in the south-east of Ukraine in XIX century.

In XIX century there was a sharp contradiction between a demand for well-educated and prepared production workers and extraordinarily low level and backwardness from the modern requirements of all branches of education in the Russian empire of that time. The position of affairs in Ukraine were considerably worse, than in the central provinces of Russia. The imperial power, trying to retain people in obedience, used school for this purpose. The Russian-language studying made difficulties in understanding of learning material by Ukrainian-speaking children. Church 
patronage limited curricula and programs and did not give the access to new scientific knowledge, textbooks, articles and books.

School and education of this period could not satisfy the necessities of people in training. Only at primary school the education was free of charge. But parents could not send their children to it as they have to work from childhood. Family could not provide their children with clothing, shoes, food. Rather high payment for studying in secondary (gymnasium) and high (universities) educational institutions was affordable only for noble families.

Primary schools of Ukraine in that period were subjected to different ministries and departments, private persons, separate organizations. However, without regard to different subordination, content of education in them did not almost differ and determined by principles of Orthodoxy, autocracy, class, national and sexual inequality. Moreover a system of schools was not developed, and considerable part of children could not go to school.

At primary schools students studied a law of God, Russian, arithmetic and singing. The position of affairs in the primary classes of province schools was not better.

In the article the question of training of teaching staff for primary classes in XIX century is examined. At the end of XVIII beginning of XIX century there was an active process of colonization of North Black Sea region. New cities such as Kherson, Mykolaiv, Odesa and a lot of small towns and villages were built. Industry, trade, shipbuilding, agriculture were in progress. The first centers of education - folk schools were established, and the question of their teaching staff was actual.

Key words: folk schools, teaching staff, branches of education, centers of education, pedagogical knowledge, «training of teachers», professional teacher, primary school.

Наприкінці XVIII - поч. XIX ст. здійснюється активний процес колонізації Північного Причорномор'я. Будуються нові міста: Херсон, Миколаїв, Одеса та інші, велика кількість містечок і сіл. Розвивається промисловість, торгівля, суднобудування, сільське господарство. 3'являються перші осередки освіти - народні школи, i, відповідно, нагальним стає й питання їх кадрового складу.

Питання формування вчительського персоналу в XIX ст. для початкових шкіл постійно висвітлювалось на сторінках «Сборника Херсонского земства», у наукових працях дореволюційних науковців та педагогів-практиків М. Чехова, В. Стоюніна, М. Демкова, Б. Влахопулова, Л. Толстого, сучасних авторів - О. Любара, О. Сухомлинського, І. Павлика, П. Тригуба, О. Тригуба та інших.

Перша в межах сучасної Миколаївської області загальноосвітня школа на 25 осіб була відкрита в 1827 році. У 30-40 роках XIX ст. вже налічувалось близько 15 шкіл, які давали початкову освіту і охоплювали зовсім незначну частину дітей шкільного віку [1, с. 7].

У 1828 році міністр народної освіти Шишков сказав, що «народної освіти в Російській імперії майже не існує» [2, с. 379], бо навіть в 1836 р. у Російській імперії було лише 661 училище. Для того щоб функціонували школи, потрібно було мати приміщення, меблі, підручники i, головне, забезпечити потужний кадровий потенціал. На той час у Росії не було розвиненої системи підготовки вчительських кадрів. Із 1784 року в Санкт-Петербурзькому головному народному училищі почалася «підготовка вчителів» [2, с. 247]. У 1786 році виникла вчительська семінарія, яка потім була перетворена на 1804 р. у педагогічний інститут. Із 1817 року в цьому інституті починають готувати вчителів для парафіяльних шкіл та народних училищ [2, с. 247-248].

У цей період більша частина вчителів початкових шкіл - відставні солдати та офіцери, волосні писарі, письменні селяни, священнослужителі та чиновники. Вони викладали в школах без будь-якої спеціальної освіти, деякі з них були ледве письменні [4, с. 8-9]. Так, наприклад, в школах державних селян в Засіллі, Снігурівці, Станіславі, Мар'їнінському, навчання проводили священики.

У селах Широка Балка, Корчарівка, Балацьке, Остапівка, Горожино, Загрядівка, Нікольське та інших - учителями були міщани. У м. Кривий Ріг, с. Покровське, Михайлівка, 
Новоіванівка (Касперівка) - унтер-офіцери вчили дітей грамоті.

Серед учителів початкових шкіл іноді зустрічалися вихідці з дворянських сімей [4, c. 93-95]. У 60-х роках ХІХ ст. спостерігається процес повільного, але невпинного зростання кількості початкових шкіл. Більшість народних шкіл в Херсонському повіті виникли між 1860 і 1865 роками [4, с. 9]. Становище сільського вчителя було доволі скрутним. Умов для нормального проведення навчального процесу не було. Під школу сільською громадою виділялися малопристосовані приміщення: церковні будинки (с. Пересадівка, Новоіванівка, Нововоронцовка, Нікольське), сторожки (с. Корчарівка), сільські розправи (с. Новокурськ, Данівка, Себіно, Баловне, Матвіївка, Балацьке, Михайлівка), будинки сільської громади (с. Новомиколаївка, Широка Балка, Новий Буг, Широке, м. Шестерне, с. Гур’ївка, Полтавка); будинки вчителів (Дудчине, Киселівка), дияконів, найманих будинках (Воєннофордштатське, с. Сергіївка, Осокорівка, Грушівка) тощо [4, с. 93-96].

Умови роботи не відповідали вимогам. Класні приміщення були темні, вологі, тісні. Заснована в с. Архангельському у 1871 році земська двокомплектна школа розміщувалася в сільській хаті. Кімнати були настільки тісні, що учні не могли виконувати письмові роботи. У с. Новогригорівка школа заснована у 1868 році, розташовувалася в тісній глинобитній хаті [5, c. 128].

Більше 36,5 \% церковнопарафіяльних шкіл й 67,7 \% шкіл грамоти Херсонської губернії були «незручні» для проведення занять [6, с. 50]. Катастрофічно не вистачало наочних посібників, методичної літератури, підручників. Загалом у 1891 році 30 відсотків початкових шкіл Херсонської губернії, за свідченням директора народних училищ В.Фармаковського, перебували в незадовільному стані [7, с. 1].

Сільський учитель, незалежно від того, у якій школі він працював - земській церковнопарафіяльній чи школі грамоти, залишався знедоленим. Селяни почасти 3 недовірою ставились до вчителя та недооцінювали його важку працю. Заробітна плата вчителя складала 40-50 крб. на рік, іноді трохи більше [4, с. 73]. Сільська громада в значній кількості випадків не могла забезпечити вчителя житлом, опаленням на зиму. У тому випадку, коли селяни не могли розрахуватися з учителем за його працю, він був вимушений ходити по домівках учнів і збирати натуроплату хлібом, борошном, зерном і т. ін.

Нерідкістю було те, коли вчителі щоденно ходили на роботу за 10-12 кілометрів. Так, учителі Погорілівської, Мішковської, Широкобалківської шкіл щоденно ходили пішки 3 м. Миколаєва на роботу.

Іноді вчителі, не маючи оселі, проживали в класних кімнатах. Сільська громада інколи надавала помешкання вчителям у зовсім не пристосованих вологих, погано опалювальних приміщеннях, це було причиною того, що вчителі часто хворіли. Не було розроблено системи соціального захисту вчителів, пенсійне законодавство на них не поширювалося.

У школу йшли вчителювати випадкові люди; відраховані з числа студентів духовної семінарії за погану успішність, просто невдахи. У с. Ковалівка вчителював п'яниця і гульвіса, син місцевого дяка. За незначну провину він забив до смерті учня С. Лежненка [8, c. 17].

У 1884 році у с. Кам'янка, що поблизу м. Очакова, відкрито церковнопарафіяльну школу. Містилася вона в церковній сторожці, де навчалося 5 хлопчиків і 2 дівчаток, і вчили їх дяк і піп-розстрига, обидва, за свідченням шкільної інспектури, «до навчання не здатні» $[9$, c. 343].

У 1864 році з появою земств з'явилися хоч і незначні, але позитивні тенденції до покращення роботи народних шкіл. Значна увага приділялася вчителям, їх нестача змусила земство Херсонського повіту у 1865 році 20 селянських хлопчиків послати вчитися на кошти земства в Херсонське повітове училище «з метою підготовки в учителі сільських шкіл» [4].

Управа запропонувала виділити кожній школі по 50 крб. для підготовки вчителів і ще в 1867 році заснувати педагогічні курси за рахунок фінансів губернського земства при Херсонській гімназії, для чого було виділено 1500 крб. Але, як стало згодом видно з журналу 
засідань учительської ради і управи 1868 року, гроші за призначенням не доходили, вони осідали в кишенях сільської влади [4]. Крім того, грошова допомога, призначена одному вчителеві, видавалась іншому, зовсім нездібному. Тому було вирішено, що допомога не повинна перевищувати суму, яка відпускається на утримання школи самою громадою, $\mathrm{i}$ допомогу видавати у вигляді додатку до заробітної плати вчителеві [4].

У 60-х роках XIX ст. головними питаннями були: де взяти гроші на утримання шкіл; звідки взяти підготовлених учителів [10, с. 133].

У цей час земство вирішило залучити до педагогічної справи жінок. Прийнята постанова про виділення по 1000 крб. щорічно на зміцнення Херсонської жіночої гімназії, у якій безкоштовно навчалися 25 земських стипендіаток, з виплатою їм стипендії [10, с. 134].

Підвищується заробітна плата вчителів. У 1873 р. вона складала від 250 до 300 крб. на рік, при готовій квартирі, опаленні, прислузі і воді [10].

Поступово підвищується якість роботи педагогів. За наказом Міністерства народної освіти в імперії з'являються зразкові класи, у тому числі і в Херсонській губернії: Тягінці, Корчарівці, Дудчині, Нововоронцовці, Новомиколаївці, Покровському, Великій Олександрівні, Архангельському, Кривому Розі, Широкому, Миколаївці, Полтавці, Привольному, Новій Одесі, Станіславі, Засіллі [10].

Підвищуються вимоги до вчителів щодо виконання своїх обов'язків. Учитель повинен вести облікові книжки шкільного майна, класний журнал, звітність по продажу книжок, дотримуватись вимог шкільної програми, яка передбачає вивчення Закону Божого, арифметики, письма, читання та співу.

Зростає навантаження на вчителя - у класах збільшується кількість учнів. При нормі у 60 учнів на одного вчителя, їхня кількість сягала до 80-90 осіб, тому у вчителів 3'являються помічники. Інколи в однокласній народній школі вчитель працював одночасно з трьома відділеннями, що, безсумнівно, призводило до зниження якості знань учнів.

За свідченням члена повітової училищної ради А. Снкуватова, у 1866 році в Херсонському повіті існувало 58 училищ, у яких працювало 54 вчителя і 21 законовчитель. Найбільша плата вчителеві складала 300 крб., найменша 22 крб. 40 коп. на рік. Найвища плата за викладання Закону Божого законовчителям складала 100 крб., а найменша 30 крб. на рік. Найбільше число учнів на одного вчителя - 120 осіб, найменше - 4 [4, с. 30-31].

На засіданнях управи пропонувалося покращити кадровий склад учителів. У результаті в Одесі та Миколаєві було створено учительські семінарії, проводилися літні курси підготовки вчителів.

Земство багато турбувалося про підвищення рівня педагогічних знань учителів. У збірнику Херсонського земства 1898 року за №8 говориться про те, що під керівництвом Бунакова у 1875 році і барона Корфа у 1881 році пройшли з'їзди вчителів. На початку 90-х років, коли замість з'їдів стали проводити курси, земство стало відпускати гроші на утримання відряджених на них учителів. Від’їджали на курси і в Москву. Так, у 1873 р. два вчителі, один з них з Новопокровської школи, були відряджені на курси до Московського політехнічного музею. Проводились такі курси і в Херсоні. 3 метою допомоги вчителям виписувались педагогічні журнали «Земская школа», «Воспитание и обучение», «Народная школа», «Русский начальный учитель», «Образование», але на 2-3 школи приходився один екземпляр. При школах створювалися педагогічні бібліотеки [10, с. 152].

Отже, у другій половині XIX століття різко зростає кількість початкових шкіл та вчителів, покращується їх якісний склад. Так, у 1895 році в народних училищах Херсонської губернії працювало 1370 вчителів. 3 них 663 закінчили вчительські семінарії і взагалі отримали спеціальну підготовку й освіту, двоє закінчили курс вищих, 704 середніх навчальних закладів. Лише один не мав права на викладання. Із 489 законовчителів 25 закінчили семінарії, 463 середні і один вищий навчальні заклади [11, с. 43].

На нашу думку, наведені факти надають можливість зробити висновок, що початкова школа в Південно-Східній Україні наприкінці XVIII - початку XIX століття пройшла складний шлях становлення і розвитку. Учительство перейшло від відставного солдата до 
освіченого професійного педагога. Незважаючи на митарства, злидні, труднощі, які пройшли вчителі і народна школа загалом, можна сказати про те, що в XIX ст. було закладено фундамент організації роботи 3 педагогічними кадрами. Вагомий внесок у забезпечення діяльності вчителів народних шкіл другої половини XIX ст. зробили земства губернії.

\section{Література}

1. Освіта на Миколаївщині у XX-XX ст. (Історичні нариси). - Миколаїв : Вид-во УДМТУ. 2. Демков М. И. Курс педагогики. - 4.2: Теория и практика воспитания. - Москва Петроград. -Изд. В. В., 1915. - 366 с. 3. Каптерев П. Ф. История русской педагогики. Петроград: Земля, 1915. - 746 с. 4. Материалы по делу народного образования в Херсонском уезде, извлеченные из дела земства членом Херсонских уездных - училищного совета и земской управы Герцешлтейном и им же составленный обзор деятельности земства Херсонского уезда в деле народного образования в период времени от открытия земских учреждений до настоящего времени. 1865-1874.- Херсон: Типография И. О. Ващенко, 1874. - 637 с. 5. Учебное заведение Одесского учебного округа, состоящее в ведении дирекций народных училищ. - Вып. 3: Таврическая дирекция. - Одесса, 1891.- С. 128. 6. Сборник Херсонского земства. -1899. - № 5 (май). - Херсон, 1899. -327 с. 7. Сборник Херсонского земства. - 1892. - № 12 (декабрь). - Херсон. - 1892. - 440 с. 8. Державний архів Одеської області, ф. Р-91, оп.1, спр. 52, 17 с. 9. Херсонские епархиальные ведомости. - 1886. № 7. - С. 343; - № 9. - 429 с. 10. Сборник Херсонского земства. -1898. - №8 (август). Херсон, 1898. - 159 с. 11. Сборник Херсонского земства. - 1896. - № 10 (октябрь). - Херсон. 1896. - 509c. 12. Народное образование в России с 60-х годов XIX века / сост. Н. В. Чехов. Москва. - По 1912. - 224 с. 13. Стоюнин В. Я. Педагогическое сочинение. - СПб : Тип. М. М. Стасюлевича, 1911. -488 с.

УДК 378.147

Тетяна Мотуз

\section{ФОРМУВАННЯ ІДЕЙ ТОЛЕРАНТНОСТІ В ПЕДАГОГІЧНІЙ ДУМЦІ УКРАЇНИ: ДЖЕРЕЛОЗНАВЧИЙ АСПЕКТ}

Мотуз Т. В. Формування ідей толерантності в педагогічній думці України: джерелознавчий аспект.

У статті здійснено аналітичний огляд та класифікацію джерелознавчої бази досліджень історії розвитку ідеї толерантності в педагогічній думці України. Виявлені джерела систематизовано в чотири групи, що представляють послідовність наукового розроблення досліджуваної проблеми. Репрезентативність сформованої джерельної бази обгрунтовано на основі джерелознавчого аналізу й синтезу з урахуванням соціокультурного контексту.

Ключові слова: історичне джерело, педагогічне джерело, джерела актованого характеру, науково-педагогічні джерела, толерантність, класифікація.

Мотуз Т. В. Формирование идей толерантности в педагогической мысли украины: источниковедческий аспект.

В статье осуществлен аналитический обзор и классификация источниковедческой базы исследований истории развития идеи толерантности в педагогической мысли Украины. Выявленные источники систематизированы в четыре группы, представляющие последовательность научной разработки исследуемой проблемы: 1) источники актированного характера (законодательные материалы международного, всеукраинского, регионального уровней: декларации, законы, постановления, приказы и др.); 2) научнопедагогические источники (монографии, статьи, исторические исследования, диссертации на соискание ученой степени доктора и кандидата наук); 3) методическая литература (учебные пособия, рекомендации, разработанные педагогическими коллективами учебных заведений разных типов, обобщение опыта, отчеты, материалы съездов, конференций) 4) источники 